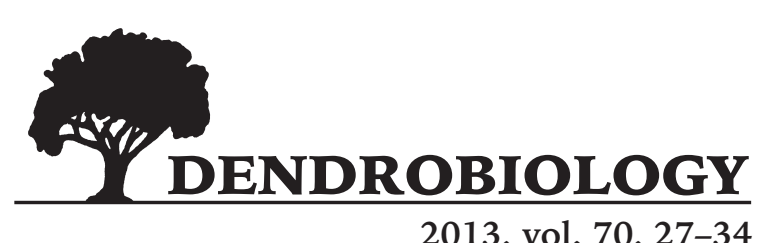

http://dx.doi.org/10.12657/denbio.070.003

\author{
Samuli Helama, Kari Mielikäinen, Mauri Timonen, Hannu Herva, \\ Heikki Tuomenvirta, Ari Venäläinen
}

\title{
Regional climatic signals in Scots pine growth with insights into snow and soil associations
}

\author{
Received: 31 May 2012; Accepted 22 November 2012
}

\begin{abstract}
We performed climatic assessments of Scots pine growth variations in Finland over recent decades by their tree-ring series and comparing growth variations to those observed in meteorological records. Tree-ring indices showed non-significant growth trends over roughly the past four decades (1972-2007). The observed growth variability was explained by connexions to the mid-summer (July) climate (temperature and, likely, cloudiness) in the north and to the spring (April) soil temperatures in the south. Tree growth was negatively associated with snow depth at the beginning of dormancy (in November, previous to the corresponding growth year) in the south and during the growing season start (May) in the north. Thus, these analyses emphasized the relevance of snow and soil data, which have usually been overlooked in studies of associations between climate and tree-ring changes.
\end{abstract}

Additional key words: Pinus sylvestris, radial growth, climate variability, soil temperature, snow depth

Addresses: S. Helama, Arctic Centre, University of Lapland, Rovaniemi, Finland; e-mail: samuli.helama@ metla.fi; K. Mielikäinen, Finnish Forest Research Institute, Vantaa Research Unit, Finland; M. Timonen, Finnish Forest Research Institute, Rovaniemi Research Unit, Finland; H. Herva, Finnish Forest Research Institute, Kolari Research Unit, Finland; H. Tuomenvirta, Finnish Meteorological Institute, Helsinki, Finland; A. Venäläinen, Finnish Meteorological Institute, Helsinki, Finland

\section{Introduction}

Climate is an universal factor driving tree growth variability. The science of dendroclimatology, a sub-field of dendrochronology, uses tree-rings to study the impact of climate variability on tree growth (Fritts 1976; Sheppard 2010). Traditionally, the dendroclimatic associations are drawn based on monthly mean air temperatures and total precipitation (Blasing et al. 1984; Fritts and Wu 1986). Similar analyses have previously been carried out also in Finland where the summer temperature and spring precipitation are often regarded as the main climatic parameters influencing the growth (Hustich and Elfving 1944; Mikola 1950; Henttonen 1984;
Lindholm 1996; Helama et al. 2004, 2005; Macias et al. 2004; Hordo et al. 2011; Korpela et al. 2011). In contrast, the present analysis used monthly mean soil temperatures and snow thickness observations as explanatory variables for radial growth. These observations were made at the same stations that measured air temperatures and precipitation (Heikinheimo and Fougstedt 1992; Helama et al. 2011). This analysis of extended data was motivated by previous suggestions that snow-melt timing and subsurface temperatures may notably influence the tree-ring growth of several conifers (Beltrami et al. 1995; Vaganov et al. 1999; Kirdyanov et al. 2003; Rossi et al. 2007; Macias Fauria et al. 2008; Nikolaev et al. 2009). 


\section{Materials and methods}

\section{Tree-ring data}

Increment cores were extracted at breast height from the stems of living Scots pine trees across the study region (Table 1) in 2007 and 2008. The sampling sites were located in the northern (9 sites, 351 trees) and southern (11 sites, 404 trees) parts of the country (Fig. 1) in forests expected to represent unmanaged conditions including forests in National Parks and nature reserves (Mielikäinen and Timonen 1996). The time-series of ring-widths were obtained by measuring consecutive tree-rings in each core. The widths were measured perpendicular to the borders between the latewood and earlywood to the nearest $0.01 \mathrm{~mm}$ with a light-microscope in Finnish Forest Research Institute laboratories. The pines of this study possessed a cambially youngest ring between the years 1650 and 1900 .

\section{Meteorological database}

The time-series of meteorological observations were compared with the statistics of pine growth. This data included the monthly means of air and soil temperatures, monthly precipitation sums, and the monthly estimates of snow depth. Starting in 1971, the six sites with meteorological stations had stored regularly updated observations of air and soil temperatures in the electronic database of the Finnish Meteorological Institute. In addition, the database stored data on snow depth and precipitation over the same interval. The air temperatures and precipitation sums were measured at a height of $2 \mathrm{~m}$. The mean monthly temperatures were calculated from intra-daily observations (Tuomenvirta 2004). The soil temperatures were measured from various depths, but the most frequently reported measurements were performed at $20 \mathrm{~cm}$ below the ground surface (Helama et al. 2011). Temperatures were measured on the $3^{\text {rd }}, 8^{\text {th }}, 13^{\text {th }}, 18^{\text {th }}$, $23^{\text {rd }}$, and $28^{\text {th }}$ day of each month; thus, the monthly mean soil temperatures were computed based on these values (Heikinheimo and Fougstedt 1992). The snow depth observations were made on the $15^{\text {th }}$ day of each month. Two stations were located in the northern sub-region (Kevo, Sodankylä), and four (Ylistaro, Maaninka, Jokioinen, Anjala) were situated in the southern sub-region (Fig. 1). The climatic data was shown to correlate over similar spatial scales (Heino 1994; Helama et al. 2011), and the data were averaged within sub-regions to provide mean time-series as dendroclimatic counterparts for the northern and southern tree-ring data.

\section{Biological growth trends}

The tree-ring series were aligned according to the ring number (the $n$th ring, counted from the innermost to the outermost ring) and the average ring-width of the series was computed. The resulting growth trend was modelled with the equation for a modified negative exponential curve (Fritts et al. 1969). This growth trend modelling was performed separately for the northern, southern, and the combined datasets (Fig. 2). The process was based on the

Table 1. The sampling sites in the northern and southern part of the country characterized by their geographical coordinates and altitudes (m) above the sea level

\begin{tabular}{|c|c|c|c|c|}
\hline Sub-region & Site & Latitude & Longitude & Altitude \\
\hline North & Angeli & $68^{\circ} 54^{\prime} 14^{\prime \prime} \mathrm{N}$ & $25^{\circ} 43^{\prime} 45^{\prime \prime} \mathrm{E}$ & 284 \\
\hline North & Hetta & $68^{\circ} 28^{\prime} 06^{\prime \prime} \mathrm{N}$ & $23^{\circ} 24^{\prime} 02^{\prime \prime} \mathrm{E}$ & 362 \\
\hline North & Iijärvi & $69^{\circ} 17^{\prime} 14^{\prime \prime} \mathrm{N}$ & $27^{\circ} 28^{\prime} 31^{\prime \prime} \mathrm{E}$ & 221 \\
\hline North & Kuttanen & $68^{\circ} 25^{\prime} 00^{\prime \prime} \mathrm{N}$ & $22^{\circ} 49^{\prime} 26^{\prime \prime} \mathrm{E}$ & 348 \\
\hline North & Muotka & $69^{\circ} 11^{\prime} 38^{\prime \prime} \mathrm{N}$ & $26^{\circ} 55^{\prime} 25^{\prime \prime} \mathrm{E}$ & 253 \\
\hline North & Pulju & $68^{\circ} 20^{\prime} 44^{\prime \prime} \mathrm{N}$ & $24^{\circ} 39^{\prime} 37^{\prime \prime} \mathrm{E}$ & 373 \\
\hline North & Riekkovaara & $68^{\circ} 28^{\prime} 22^{\prime \prime} \mathrm{N}$ & $27^{\circ} 17^{\prime} 30^{\prime \prime} \mathrm{E}$ & 268 \\
\hline North & Sevetti & $69^{\circ} 31^{\prime} 15^{\prime \prime} \mathrm{N}$ & $28^{\circ} 33^{\prime} 21^{\prime \prime} \mathrm{E}$ & 122 \\
\hline North & Tämäkkä & $68^{\circ} 13^{\prime} 56^{\prime \prime} \mathrm{N}$ & $26^{\circ} 21^{\prime} 37^{\prime \prime} \mathrm{E}$ & 329 \\
\hline South & Helvetinjärvi & $62^{\circ} 00^{\prime} 52^{\prime \prime} \mathrm{N}$ & $23^{\circ} 53^{\prime} 36^{\prime \prime} \mathrm{E}$ & 177 \\
\hline South & Jongunjoki & $63^{\circ} 37^{\prime} 20^{\prime \prime} \mathrm{N}$ & $29^{\circ} 59^{\prime} 42^{\prime \prime} \mathrm{E}$ & 130 \\
\hline South & Jonkeri & $63^{\circ} 49^{\prime} 53^{\prime \prime} \mathrm{N}$ & $29^{\circ} 41^{\prime} 51^{\prime \prime} \mathrm{E}$ & 225 \\
\hline South & Kitkasuo & $63^{\circ} 38^{\prime} 16^{\prime \prime} \mathrm{N}$ & $30^{\circ} 00^{\prime} 35^{\prime \prime} \mathrm{E}$ & 145 \\
\hline South & Koivusuo & $62^{\circ} 58^{\prime} 37^{\prime \prime} \mathrm{N}$ & $31^{\circ} 24^{\prime} 27^{\prime \prime} \mathrm{E}$ & 199 \\
\hline South & Patvinsuo & $63^{\circ} 08^{\prime} 25^{\prime \prime} \mathrm{N}$ & $30^{\circ} 40^{\prime} 24^{\prime \prime} \mathrm{E}$ & 179 \\
\hline South & Petkeljärvi & $62^{\circ} 34^{\prime} 37^{\prime \prime} \mathrm{N}$ & $31^{\circ} 11^{\prime} 17^{\prime \prime} \mathrm{E}$ & 160 \\
\hline South & Pyhä-Häkki & $62^{\circ} 51 ' 15^{\prime \prime} \mathrm{N}$ & $25^{\circ} 27^{\prime} 57^{\prime \prime} \mathrm{E}$ & 166 \\
\hline South & Ruunaa & $63^{\circ} 25^{\prime} 12^{\prime \prime} \mathrm{N}$ & $30^{\circ} 34^{\prime} 14^{\prime \prime} \mathrm{E}$ & 155 \\
\hline South & Salamajärvi & $62^{\circ} 00^{\prime} 52^{\prime \prime} \mathrm{N}$ & $23^{\circ} 53^{\prime} 36^{\prime \prime} \mathrm{E}$ & 187 \\
\hline South & Vesijako & $61^{\circ} 21^{\prime} 18^{\prime \prime} \mathrm{N}$ & $25^{\circ} 06^{\prime} 10^{\prime \prime} \mathrm{E}$ & 152 \\
\hline
\end{tabular}




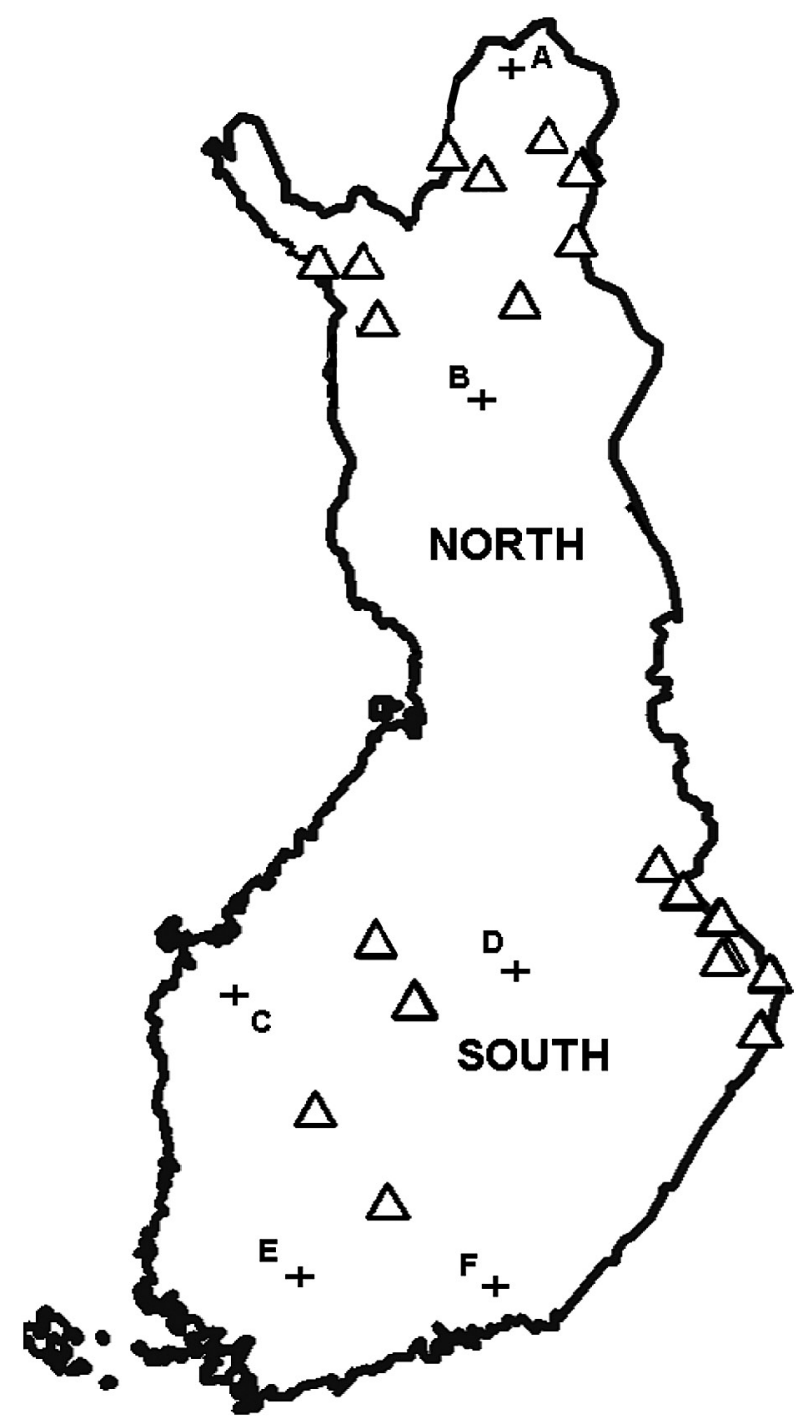

Fig. 1. A map of Finland showing the tree-ring sites (triangles) in northern and southern sub-regions and the meteorological stations (crosses; A - Kevo, B - Sodankylä, C - Ylistaro, D - Maaninka, E - Jokioinen, and F-Anjala)

regional-curve-standardization (RCS; Briffa et al. 1992). The resulting growth trend model, which represented ageing over the full region, was accordingly termed the RCS-curve. The models that represented the ageing over only the northern or southern sub-regions were termed the SRCS(N) and SRCS(S)-curves. We removed cambial trends from the tree-ring data by dividing the value of observed ring-width by the modelled curve value. The standardized tree-ring indices (Fritts 1976) obtained in this way were termed RCS-indices. We also standardized the northern and southern tree-ring series with the corresponding RCS- or the SRCS curve values to obtain RCS- and SRCS-indices. These indices were aligned according to the calendar year and averaged to obtain northern and southern mean series with the biweight robust mean procedure (Cook et al. 1990).
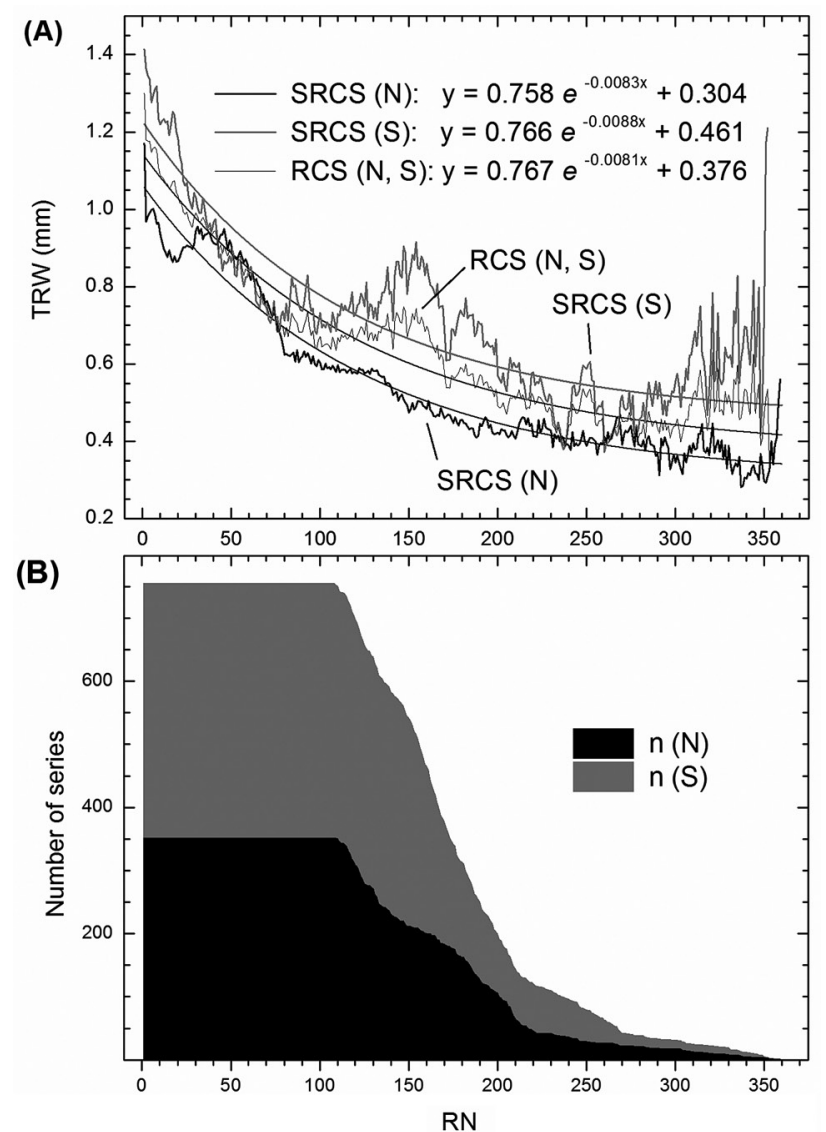

Fig. 2. Mean tree-ring widths (TRW) as a function of ring number (RN) (A). The number of tree-ring series to calculate the mean function (B). The cambial growth trend modeled using the modified negative exponential function constituting the RCS- and SRCS-curves for northern $(\mathrm{N})$, southern $(\mathrm{S})$ and combined $(\mathrm{N}, \mathrm{S})$ datasets. RCS and SRSC stand for regional curve standardization and sub-regional curve standardization, respectively

\section{Climatic assessments}

Previous estimations have shown that the forest growth in the study region had increased profoundly since the 1970s. This interval overlapped with the data used in the present study from the electronic database of the Finnish Meteorological Institute. The growth of pines was compared with the monthly climate data during a twelve-month season from October of previous year through September of the growth year. For snow depth data, the comparisons excluded snowless months; that is, from June through September in the north and from May through October in the south. These temporal constraints on the data enabled comparisons between growth trends and climates during the period of 1972-2007. Pearson correlation coefficients were calculated to determine associations between the tree-rings and meteorological data; this was performed separately for the northern and southern sub-regions. 
A multiple linear regression was applied as a response function (1972-2007), where the independent and dependent data were meteorological and tree-ring series means, respectively. Based on Lindholm (1996), acceptable models were chosen with a stepwise selection procedure; we set the criteria for predictor entry and removal at an F-statistic probability of $<0.05$ and $<0.10$, respectively. Response functions were calculated separately for the northern and southern datasets. The coefficient of correlation was computed and shown for the chosen models.

\section{Results}

\section{Tree-ring dataset}

The overall level of tree-ring indices was influenced by the RCS- and SRCS-models. Standardization with the RCS-curves resulted in lower and higher indices, in the northern and southern sub-regions, respectively, compared to standardization with the SRCS curves (Fig. 3). Based on the realization of Cook et al. (1995), these differences were expected, because the RCS trend model (see Fig. 2) allowed a systematic over- or underestimation of the growth variations due to spatially varying conditions.
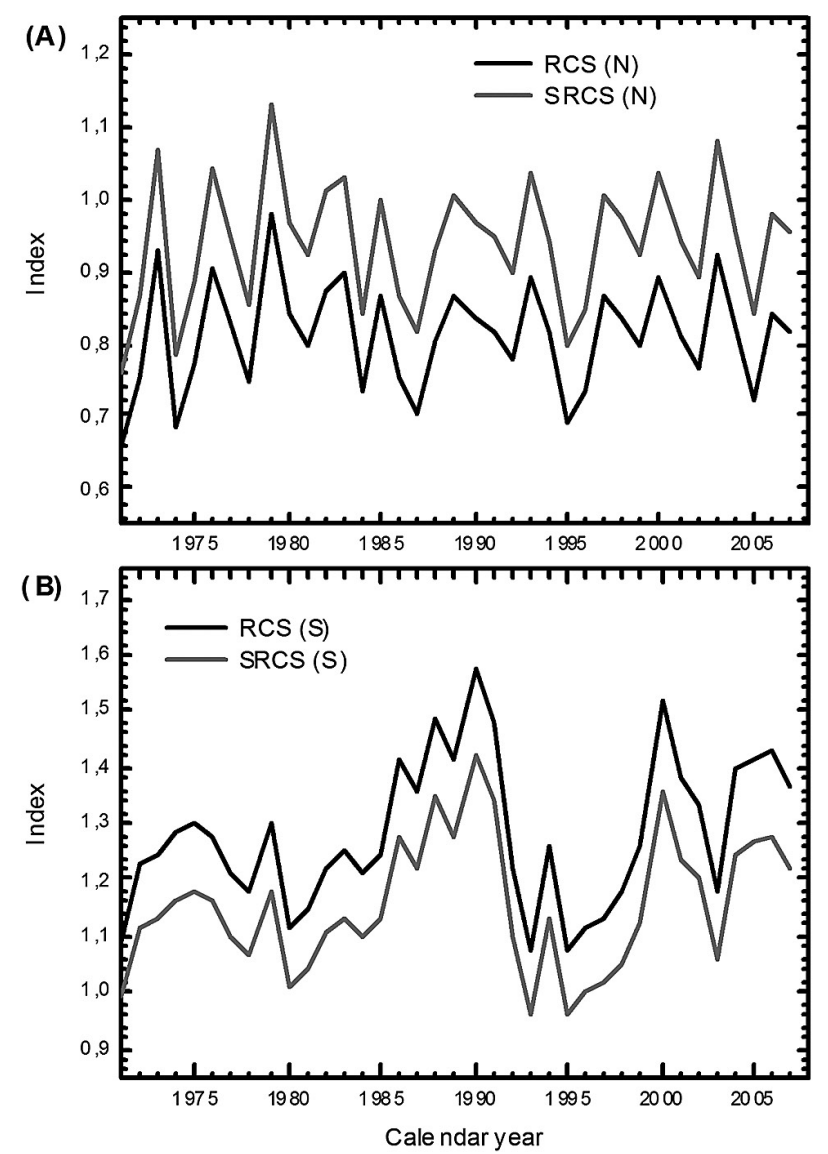

Fig. 3. Radial growth variations as depicted using RCS- and SRCS-indices for the northern (A) and southern (B) sub-regions since 1972
However, the RCS-indices were highly similar to the SRCS-indices in the relative changes within each sub-region (Fig. 3). Highly positive Pearson correlation coefficients were found between the RCS- and SRCS-indices. There were $r=0.998$ both in the north and south for the period 1972-2007. Thus, the choice of growth model (RCS or SRCS) did not alter the results. In contrast, the growth variations in the mean index series of northern pines and southern pines were clearly dissimilar. Pearson correlation coefficient between the northern and southern RCS-indices was 0.036. Calculated using SRCS-indices, the correlation between the north and south was 0.051. These low correlations indicated that the growth has been influenced by different factors in the northern and southern regions.

\section{Climatic correlations}

Northern and southern pine growth trends were found to correlate differently with climate parameters (Fig. 4). In the north, the tree-ring growth correlated positively with July air and soil temperatures and with

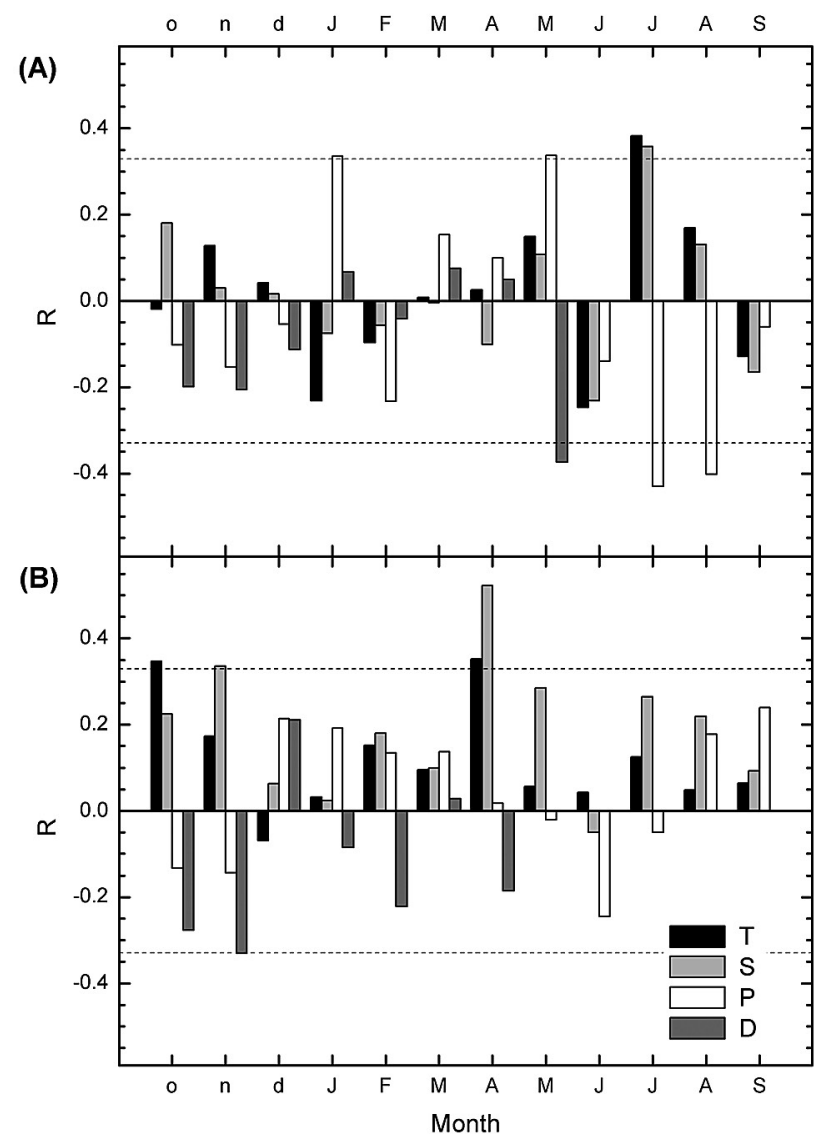

Fig. 4. Pearson correlations (R) between the growth and monthly meteorological variables. Tree-rings of northern (A) and southern (B) sub-regions were compared separately to air temperature $(T)$, soil temperature $(S)$, precipitation (P) and snow depth (D) variables of the previous (small letters) and concurrent year (capital letters). The levels of statistical significance ( 0.05 level) are indicated as horizontal lines 
Table 2. Response functions by multiple regression where the dependent (D) and independent (I1, I2) variables were the RCS/SRCS-indices (Fig. 3) and the meteorological variables in the northern (N) and southern (S) sub-regions. The obtained models were characterized by the correlation $(\mathrm{R})$ between the observed and modeled growth, the parameterized slope for I1 (S1) and I2 (S2) and their standard errors (S1E, S2E) and the constant (C) with its error (CE). Monthly climatic variables to be significantly related to growth were denoted as P-07 (precipitation in July), D-05 (snow depth in May), S-04 (soil temperature in April) and D-11 (snow depth in November in the previous year)

\begin{tabular}{llcccccccc}
\hline \multicolumn{1}{c}{ D } & I1 & I2 & R & S1 & S1E & S2 & S2E & C & CE \\
\hline RCS (N) & P-07 & none & 0.422 & -0.0010 & 0.0004 & - & - & 0.8816 & 0.0263 \\
RCS (N) & P-07 & D-05 & 0.608 & -0.0011 & 0.0003 & -0.0018 & 0.0006 & 0.9217 & 0.0265 \\
SRCS (N) & P-07 & none & 0.406 & -0.0011 & 0.0004 & - & - & 1.0162 & 0.0306 \\
SRCS (N) & P-07 & D-05 & 0.598 & -0.0012 & 0.0004 & -0.0021 & 0.0007 & 1.0627 & 0.0310 \\
RCS (S) & S-04 & none & 0.573 & 0.0974 & 0.0239 & - & - & 1.2373 & 0.0214 \\
RCS (S) & S-04 & D-11 & 0.673 & 0.0969 & 0.0219 & -0.0089 & 0.0033 & 1.2694 & 0.0228 \\
SRCS (S) & P-04 & none & 0.555 & 0.0845 & 0.0217 & - & - & 1.1169 & 0.0194 \\
SRCS (S) & P-04 & D-11 & 0.657 & 0.0840 & 0.0200 & -0.0080 & 0.0030 & 1.1455 & 0.0208 \\
\hline
\end{tabular}

January and May precipitation levels. In contrast, negative correlations were found with July and August precipitation levels and with May snow depth (Fig. $4 a)$. Of note, the negative correlation to the August precipitation level was considered borderline, because wood formation ends within the first half of this month in northern Finland (Schmitt et al. 2004).

In the south, the most profound correlation was found between tree-ring growth and April soil temperatures (Fig. 4b).The April air temperature also correlated positively with growth, but this relationship was considerably weaker than the impact of the soil temperature. Notably, a high correlation was also found between tree-ring growth and October air temperature (of the previous calendar year) and the November soil temperature. Nevertheless, there was a highly negative correlation between tree-ring growth and the snow depth at the beginning of dormancy (November of previous calendar year).

\section{Response functions}

The most parsimonious regression models included independent variables of the July precipitation level and the May snow depth for the northern pines, and the April mean soil temperature and November snow depth for southern pines (Table 2). The response functions explained up to 45 percent of the growth variance over the period of interest. Interestingly, snow accumulation and snow melt during the beginning of dormancy and during the growing season were validated as essential parameters for explaining the southern and northern pine growth variability, respectively.

\section{Discussion}

\section{Climatic signals in the north}

In the north, the climatic connexions during mid-summer were evident (Fig. 4a). Our results agreed with several previous studies (Hustich and Elfving 1944; Mikola 1950; Henttonen 1984; Lindholm 1996; Helama et al. 2004, 2005; Macias et al. 2004; Hordo et al. 2011; Korpela et al. 2011) that showed that tree-ring growth correlated positively with the mean air temperatures of July. We also found a nearly identical coefficient of correlation $\left(\mathrm{r}_{\mathrm{AIR}}=0.38\right.$ versus $r_{\text {SoIL }}=0.36$ ) between tree-ring growth and the mean soil temperatures of July; this likely reflected the close connectedness between the air and soil temperatures during the mid-summer months in the region (Helama et al. 2011). However, our data indicated that, relative to temperatures, the more decisive correlation was between the tree-ring growth and summer precipitation. This finding was similar to the results of a related study (Helama 2011), which showed that the tree-ring growth correlation to summer precipitation closely followed the correlative patterns between the mid-summer precipitation and temperature. That is, rainy summers are cloudy; therefore, on average, they are cooler than summers with less rain (Heino 1994). Moreover, the cloudiness reduces photosynthetically active radiation (PAR). Previously, in the northern sub-region, the association between the modelled PAR and tree-ring growth was shown to resemble, year-to-year, the corresponding time-series. This resemblance was particularly clear over the latter half of the 20th century (Hari and Nöjd 2009). However, the link between the July temperature and tree-ring growth was demonstrated to hold for the past three centuries (Helama et al. 2004). Lastly, it is notable that the present sample represented tree-ring data from northern Finland (Lapland); alternatively, many previous studies analysed correlations between the timberline tree-ring growth and summer temperatures. This spatial difference could explain the relatively lower correlation we found between the tree-ring widths and summer temperatures compared to those reported in previous 
studies that were restricted to ecotone datasets (e.g. Lindholm 1996; Helama et al. 2004, 2005).

Northern pine growth reacted negatively to increased snow thickness in late spring (May). Similarly, it was previously shown that northern conifers showed delayed cambial activity when the melting of snow was delayed in the beginning of the growing reason (Vaganov et al. 1999; Kirdyanov et al. 2003). The persistent snow cover may cool the soil due to the effects of albedo and latent heat (Zhang et al. 2001; Zhang 2005). This dendroclimatic correlation could be indirectly associated with the positive tree-ring growth response to precipitation in the concurrent month (Fig. 4a); probably due to the rain that falls in advance of the snow melting, as previously assumed for northern Fennoscandia (Kirchhefer 2001; Macias et al. 2004). Another snow-related correlation showed that pines reacted positively to mid-winter (January) precipitation. This association probably represents the positive influence that snow cover has on trees during the cold season; a lack of snow is known to cause premature yellowing of pine needles (Jalkanen 1993). Our results clarified these relationships, because we found that the January precipitation levels correlated better with the mean snow depth over the winter season (January through March; $r=0.61$ ) than with the January snow depth $(\mathrm{r}=0.49)$.Thus, the January precipitation level probably contributes considerably towards the snow conditions over the whole winter season.

\section{Climatic signals in the south}

In the south, the tree-ring growth showed a markedly higher positive correlation to the mean April soil temperature than to the mean April air temperature $\left(r_{\text {SOIL }}=0.52\right.$ vs. $r_{\text {AIR }}=0.35$, respectively $)$. Recently, similar correlations were derived in a dendroclimatic study in Central Yakutia. There, the radial growth of the Scots pine showed a higher positive correlation with April soil temperature $(\sim 0.4)$ than with April air temperature $(\sim 0.2)$ (Nikolaev et al. 2009). Actually, the link between the April air temperatures and Scots pine growth is among the most controversial tree-ring correlations discussed in Finland and adjacent areas. This dendroclimatic association (Laitakari 1920; Holopainen et al. 2006; Helama et al. 2012; Hordo et al. 2011) has not been significant in all studies (e.g., Henttonen 1984). Here, we showed that the April climate could influence the tree-ring growth primarily via soil temperatures. In fact, the soil temperatures in April depend on both concurrent air temperatures and the prevailing snow conditions; nevertheless, spatial variations are more obvious in soil than air temperatures within the sub-region (Helama et al. 2011). These spatial differences may partly explain the lack of a correlation between tree-ring growth and April conditions in any particular site of a given re- gion. Therefore, we hypothesize that the dendroclimatic correlation to April air temperatures may reflect a primary association between tree-ring growth and April soil temperature, particularly in sites where air and soil temperatures are highly connected.

The southern pines responded negatively to increased snow thickness in the November previous to the growth year. This was a response to natural conditions at the beginning of the snow accumulation in autumn; i.e. when fresh snow may have a relatively high albedo, but the thin layer of snow may not yet provide sufficient thermoinsulation (Zhang et al. 2001; Zhang 2005). During this time of year, in the study region, the cooler air temperatures were associated with an increased likelihood of snowfall (rather than rain) and the snowpack amplified the concomitant cooling of the soil. The influence of this air-soil temperature decoupling was evident, because pine growth was consistently and significantly correlated with soil temperature and snow thickness, but not with air temperatures in the of the same month (Fig. $4 \mathrm{~b})$. The frost hardening of Scots pine roots is mainly determined by soil temperature; however, the fine roots have been shown to lack hardening at low, non-freezing temperatures (Ryyppö et al. 1998). Perhaps the freezing injury to roots is particularly likely to occur at this time of year (November), when soil temperatures typically remain slightly above zero degrees centigrade in the southern sub-region (Helama et al. 2011).

\section{Acknowledgements}

We thank Pirkko Karlsson for deriving relevant variables from the electronic database of the Finnish Meteorological Institute. We gratefully acknowledge support from the Niemi foundation, the Academy of Finland (122033, 217724), and Metsämiesten Säätiö.

\section{References}

Beltrami H., Chapman D.S., Archambault S., Bergeron Y. 1995. Reconstruction of high resolution ground temperature histories combining dendrochronological and geothermal data. Earth and Planetary Science Letters 136: 437-445.

Blasing T.J., Solomon A.M., Duvick D.N. 1984. Response functions revisited. Tree-Ring Bulletin 44: 1-15.

Briffa K.R., Jones P.D., Bartholin T.S., Eckstein D., Schweingruber F.H., Karlén W., Zetterberg P., Eronen M. 1992. Fennoscandian summers from ad 500: temperature changes on short and long timescales. Climate Dynamics 7: 111-119.

Cook E.R., Briffa K.R., Meko D.M., Graybill D.A., Funkhouser G. 1995. The 'segment length curse' in long tree-ring chronology development for palaeoclimatic studies. The Holocene 5: 229-237. 
Cook E.R., Shiyatov S., Mazepa V. 1990. Estimation of the Mean Chronology. In: Methods of Dendrochronology: Applications in the Environmental Science. Cook E.R., Kairiukstis L. (eds.). Kluwer Academic Publishers, Dordrecht, pp. 123-132.

Fritts H.C. 1976. Tree rings and climate. Academic Press, London.

Fritts H.C., Wu X. 1986. A Comparison between response function analysis and other regression techniques. Tree-Ring Bulletin 46: 31-46.

Fritts H.C., Mosimann J.E., Bottorff C.P. 1969. A revised computer program for standardizing tree-ring series. Tree-Ring Bulletin 29: 15-20.

Hari P., Nöjd P. 2009. The effect of temperature and PAR on the annual photosynthetic production of Scots pine in northern Finland during 1906-2002. Boreal Environmental Research (suppl. A) 14: 5-18.

Heikinheimo M., Fougstedt B. 1992. Statistic of soil temperature in Finland 1971-1990. Meteorological Publications 22: 1-75.

Heino R. 1994. Climate in Finland during the period of meteorological observations. Finnish Meteorological Institute Contributions 12: 1-209.

Helama S. 2011. Climate and Scots pine tree-rings in Utsjoki-Kevo district (North-East Finnish Lapland) during the 20th century, with special emphasis on mid-summer connexions. Reports from the Kevo Subarctic Research Station 24: 129-138.

Helama S., Holopainen J., Timonen M., Ogurtsov M.G., Lindholm M., Meriläinen J., Eronen M. 2004. Comparison of living-tree and subfossil ringwidths with summer temperatures from 18th, 19th and 20th centuries in northern Finland. Dendrochronologia 21: 147-154.

Helama S., Lindholm M., Meriläinen J., Timonen M., Eronen M. 2005. Multicentennial ring-width chronologies of Scots pine along north-south gradient across Finland. Tree-Ring Research 61: 21-32.

Helama S., Tuomenvirta H., Venäläinen A. 2011. Boreal and subarctic soils under climatic change. Global and Planetary Change 79: 37-.

Helama S., Läänelaid A., Raisio J., Tuomenvirta H. 2012. Mortality of urban pines in Helsinki explored using tree-rings and climate records. Trees 26: 353-362.

Henttonen H. 1984. The dependence of annual ring indices on some climatic factors. Acta Forestalia Fennica 186: 1-38.

Holopainen J., Helama S., Timonen M. 2006. Plant phenological data and tree-rings as palaeoclimate indicators since AD 1750 in SW Finland. International Journal of Biometeorology 51: 61-72.

Hordo M., Henttonen H.M., Mäkinen H., Helama S., Kiviste A. 2011. Annual growth variation of Scots pine in Estonia and Finland. Baltic Forestry 17: 35-49.

Hustich I., Elfving G. 1944. Die Radialzuwachsvariationen der Waldgrenzkiefer. Societas Scientiarum Fennica Commentationes Biologicae 9 (8): $1-18$.

Jalkanen R. 1993. Defoliation of pines caused by injury to roots resulting from low temperatures. Finnish Forest Research Institute, Research Papers 451: 77-88.

Kirchhefer A.J. 2001. Reconstruction of summer temperature from tree rings of Scots pine, Pinus sylvestris L., in coastal northern Norway. The Holocene 11: 41-52.

Kirdyanov A., Hughes M., Vaganov E., Schweingruber F., Silkin P. 2003. The importance of early summer temperature and date of snow melt for tree growth in the Siberian Subarctic. Trees 17: 61-69.

Korpela M., Nöjd P., Hollmén J., Mäkinen H., Sulkava M., Hari P. 2011. Photosynthesis, temperature and radial growth of Scots pine in northern Finland: identifying the influential time intervals. Trees 25: 323-332.

Laitakari E. 1920. Tutkimuksia sääsuhteiden vaikutuksesta männyn pituus- ja paksuuskasvuun. Referat: Untersuchungen über die Einwirkung der Witterungsverhältnisse auf den Längen- und Dickenwachstum der Kiefer. Acta Forestalia Fennica 17: 1-57.

Lindholm M. 1996. Reconstruction of past climate from ring-width chronologies of Scots pine (Pinus sylvestris L.) at the northern forest limit in Fennoscandia. University of Joensuu, Publications in Sciences 40: 1-169.

Macias M., Timonen M., Kirchhefer A., Lindholm M., Eronen M., Gutierrez E. 2004. Growth variability of Scots pine along a west-east gradient across northern Fennoscandia: a dendroclimatic approach. Arctic, Antarctic and Alpine Research 36: 565-574.

Macias Fauria M., Helle T., Niva A., Posio H., Timonen M. 2008. Removal of the lichen mat by reindeer enhances tree growth in a northern Scots pine forest. Canadian Journal of Forest Research 38: 2981-2993.

Mielikäinen K., Timonen M. 1996. Growth trends of Scots pine (Pinus sylvestris, L.) in unmanaged and regularly managed stands in Southern and Central Finland. In: Growth Trends in European Forests. European Forest Institute. Spiecker H., Köhl M., Mielikäinen K., Skovsgaard J.P. (eds.). European Forest Institute, Research Report 5: 41-59.

Mikola P. 1950. Puiden kasvun vaihteluista ja niiden merkityksestä kasvututkimuksissa. Summary: On variations in tree growth and their signifi- 
cance to growth studies. Communicationes Instituti Forestalis Fenniae 38(5): 1-131.

Nikolaev A.N., Fedorov P.P., Desyatkin A.R. 2009. Influence of climate and soil hydrothermal regime on radial growth of Larix cajanderi and Pinus sylvestris in Central Yakutia, Russia. Scandinavian Journal of Forest Research 24: 217-226.

Rossi S., Deslauriers A., Anfodillo T., Carraro V. 2007. Evidence of threshold temperatures for xylogenesis in conifers at high altitudes. Oecologia 152: 1-12.

Ryyppö A., Repo T., Vapaavuori E. 1998. Development of freezing tolerance in roots and shoots of Scots pine seedlings at nonfreezing temperatures. Canadian Journal of Forest Research 28: 557-565.

Schmitt U., Jalkanen R., Eckstein D. 2004. Cambium dynamics of Pinus sylvestris and Betula spp. in the northern boreal forest in Finland. Silva Fennica 38: 167-178.
Sheppard P.R. 2010. Dendroclimatology: extracting climate from trees. Wiley Interdisciplinary Reviews - Climate Change 1: 343-352.

Tuomenvirta H. 2004. Reliable estimation of climatic variations in Finland: Finnish Meteorological Institute Contributions 43: 1-79.

Vaganov E.A., Hughes M.K., Kirdyanov A.V., Schweinguber F.H., Silkin P.P. 1999. Influence of snowfall and melt timing on tree growth in subarctic Eurasia. Nature 400: 149-151.

Zhang T. 2005. Influence of the seasonal snow cover on the ground thermal regime: An overview. Reviews of Geophysics 43: Art no. RG4002 doi:10.1029/2004RG000157.

Zhang T., Barry R.G., Gilichinsky D., Bykhovets S.S., Sorokovikov V.A., Ye J. 2001. An amplified signal of climatic change in soil temperatures during the last century at Irkutsk, Russia. Climatic Change 49: 41-76. 